\title{
20. Dringlichkeitsfragen bei der Erstversorgung kombinierter arterieller Verletzungen im Kindesalter
}

\author{
J. D. Gruss*, R. Daum und J. Vogr-Heidelberg \\ Questions of Priority in Immediate Treatment of Combined Arterial \\ Injuries in Children \\ Summary. Owing to the high degree of elasticity of the healthy vessel wall \\ in children, vascular injuries in childhood are rare. Whereas in the diagnosis of \\ direct, acutely penetrating injuries angiography can often be omitted, it is indis- \\ pensable in blunt vascular injuries. Reconstruction is done, according to type and \\ extent of the injury, by direct vessel suture, vein patch or transplantation of an \\ autoplastic vein segment. 12 children, mostly with serious combined injuries with \\ vessel involvement, were re-examined clinically and angiographically. The recon- \\ structed vessels were functional without any restriction in all cases.
}

Zusammenfassung. Wegen der hohen Elastizität der gesunden kindlichen Gefäßwand stellen Gefäßverletzungen im Kindesalter Seltenheiten dar. Während in der Diagnostik der direkten, scharf penetrierenden Verletzungen oft auf die Angiographie verzichtet werden kann, ist diese unerläßlich für stumpfe Gefäßverletzungen. Die Rekonstruktion geschieht je nach Art und Ausdehnung der Verletzung durch direkte Gefäßnaht, Venepatch oder Transplantation eines autoplastischen Venensegmentes. Zwölf Kinder, meist mit schweren Kombinationsverletzungen unter Gefäßbeteiligung wurden klinisch und angiographisch nachuntersucht; in allen Fällen waren die rekonstruierten Gefäße ohne Einschränkung funktionstüchtig.

\section{Zur Erstversorgung der Extremitätenfrakturen bei über 500 Kombinationsverletzten}

\author{
W. Reichmann*, H. Ladschke, A. Jussen und W. Simmioh-Köln
}

\section{Primary Surgical Care of Fractures of the Limbs in over 500 Patients with Multiple Injuries}

Summary. Our experiences with these serious accident cases can be summarized briefly in a few sentences:

1. In states of protracted shock, in the presence of impaired central regulation, persistent difficulties of respiration and of course also if the prognosis is hopeless, any surgical measures in connection with the limb fractures are contra-indicated.

2. It has proved to be important to handle the injured limbs with the greatest care and immobilize them at the scene of the accident and during transport to hospital. This is best achieved with transparent aircushion-splints which can be left in position until further treatment is possible in the hospital.

3. Conservative methods of treatment seem to us to be best suited for primary surgical care, and in our opinion this also applies to open fractures. Primary osteosynthesis, which is only justified in the sense of an $\mathrm{AO}$, is in our opinion only very rarely indicated. 